\title{
Exploring a Flipped Learning Approach in Teaching Grammar for ESL Students
}

\author{
Chelster Sherralyn Jeoffrey Pudin \\ Centre for the Promotion of Knowledge and Language, Universiti Malaysia Sabah. \\ e-mail: chelster@ums.edu.my
}

\begin{abstract}
:
In light of the recent implementation of MOOC, the world of academia has been abuzz about incorporating flipped learning as part of blended learning in the classroom. Educators have been experimenting and exploring with it using different approaches. Flipped learning is basically a pedagogical model which reverses classroom activities. Materials or contents are provided online (in learning management system or other learning platforms) and students will study the material prior coming to class. Therefore, classroom time can be used to engage in activities such as problem solving, discussion and analysis. This study set out to explore the effects of flipped learning approach in a grammar classroom through students' perceptions on its effectiveness and feasibility. A total of 120 students with higher Malaysian University Entrance Test (MUET) were asked to complete a questionnaire which is then analysed through SPSS version 24. The analysis of the findings showed that most of the students were keen to learn grammar through flipped classroom as opposed to traditional grammar classroom. The findings of this study give ESL practitioners a better insight into students' preference in learning grammar and ways to create better teaching through blended learning.

Keywords: Flipped learning, Grammar classroom, ESL students perceptions'
\end{abstract}




\section{Introduction}

For decades, the higher education system in Malaysia has seen its courses delivered on a standard fourteen weeks of face-to-face lectures and tutorials. This is despite the fact that technology has seen an advancement in providing free flexible access to materials and information. As tradition dictates, a number of hours should be put aside for formal lecture and tutorials. However, as more studies have been conducted on the ineffectiveness of traditional lecture to students' learning, recently in 2012, MOOC (Massive Open Online Courses) has been introduced to the world of academia as a way to engage active learning for students. It serves as an interactive user forums to support community interactions among students, professors, and teaching assistants and it is free.

Education today in the globalised world is about adapting to changing world. How and what we teach has to change as well. Learners learn anywhere and anytime without confinement of classroom (Alias, 2010). Hence, students learn more effectively when the delivery of lectures is blended with the use of technology and can be learned at flexible hours. Blended learning an approach that combines face to face instruction with technology, emphasizing customised learning (Alias, 2014) while flexible learning opportunity to improve students learning experience through flexibility in time, pace, mode of study, teaching approach, forms of assessment and staffing. Therefore, blended learning and flexible learning can enrich learning experience, optimise student engagement, to achieve deep meaningful learning (Alias, 2014).

One approach to achieve deep and meaningful learning is through a 'flipped classroom'. Flipped classroom was first introduced by Baker (2000) and Lage et al.(2000), and popularized through online videos and activities by many others. Studies have shown that the average concentration span of adult is less than twenty minutes. In order to make a one hour lesson interesting, is to create a video that lasts for ten to fifteen minutes which can cover a forty minutes lesson. The video is then uploaded to any learning platforms for students to view. By doing this, a flipped classroom has just been created. In essence, the flipped classroom basically reverses classroom activities. Materials or contents are provided online (in learning management system or other learning platforms) and students will study the material prior coming to class. Therefore, classroom time can be used to engage in activities such as problem solving, discussion and analysis.

The purpose of this study is to explore the effects of flipped learning approach in a grammar classroom through students' perceptions. It is important to determine students' likes or dislikes for a flipped classroom because it will decide whether the instructor should continue with this approach. Also, this study hopes to provide information about the effectiveness and feasibility of a flipped classroom to educators who wish to implement it in the grammar classroom.

There are three research questions that were formulated as a focus to this study. They are: 
1. What are the students' perceptions of the flipped classroom in learning grammar?

2. Do students' perceive flipped classroom supports their learning grammar?

3. What are the ways to improve flipped classroom in learning grammar?

\section{Literature Review}

The question of how does an educator make a course more exciting, interesting, engaging, fun, yet effective is not a stranger to any teachers these days. In the teaching of grammar, most teachers have come a long way in coming up with strategies to teach grammar in a fun way knowing for a fact that grammar is one aspect of a language that can be very dry and students tend to find it boring. Traditional grammar classroom tends to be either inductive or deductive. The shortcoming of a traditional classroom is class period is too short, not enough time for reflection and questioning, not enough time for discussion and interaction and less opportunity for active learning. By realising this, an active approach to learning has been identified to make teaching and learning grammar more fun and interactive in the classroom. Prince (2004) describes active learning as requiring students to do meaningful learning activities and think about what they are doing. These learning environments are student-centred in that it is through student activity with the guidance of the teacher that learning occurs. In general, Prince (2004) presents significant evidence of the benefits of active learning. In addition to the benefits of active learning described by Prince (2004), Baeten et al. (2010) find that studentcentred learning approaches are more likely (among other factors) to lead to a deep approach to learning by students.

A "flipped classroom" approach (Baker, 2000), also known as an "inverted classroom" (Lage et al., 2000), is one approach that can be used to actively engage students in their learning. The approach does this very explicitly, by bringing active student engagement with the material (such as problem-solving, case studies usually in collaboration with other students) directly into the classroom whilst moving more passive activities (such as reading course notes and textbooks and viewing/listening to lectures) outside of the classroom. Conversely, under a traditional didactic lecture structure this active student engagement is left to a single one hour tutorial each week, and then outside the classroom to individual study and/or informal study groups.

Flipped classroom is beneficial to be applied in the grammar classroom because it presents more effective active learning, the teacher role is strengthened, time is used more efficiently, more face to face time (interactively), peer learning is enhanced, greater control of content delivery, assimilation of knowledge can be observed and students can learn on demand (Alias, 2010).

However, academic research into student perceptions and the effectiveness of a flipped classroom is relatively limited at present, with the majority of commentary coming in the form of informal weblogs and the like. Bishop and Verleger (2013) provide a recent survey of research into the flipped classroom approach and report on eleven studies that have investigated student perceptions of the flipped 
classroom, with results being relatively consistent in that general student opinion of the flipped classroom tends to be positive, with a significant minority being opposed. On the other hand, Knight and Wood (2005) found that, while results for student learning were positive, both students and teachers found that there was some initial discomfort adjusting to the decreased lectures which meant less transmission of information from instructor to student. This is a valuable lesson for flipped classroom adopters to understand. A transition to a new instructional model, regardless of success, may involve uneasiness among the participants.

\section{Methodology}

This study adopted a quantitative method involving a written questionnaire for data collection and analysis.

\subsection{Subjects}

A total of 120 students with higher Malaysian University Entrance Test (MUET) were selected as the subjects for the study. The subjects were first year students from the Faculty of Engineering as well as from the Faculty of Psychology and Education (TESL). These subjects have obtained a higher Malaysian University Entrance Test (MUET) results that range from Bands 3, 4 and 5. As a requirement from the university, students with higher band of MUET (Band 3, 4, and 5) will take advanced English courses at the Centre for the Promotion of Knowledge and Language. Since the subjects were in their first year, they were to take UB00602 Grammar in Context. This course is the crucial course related to the study.

\subsection{Instrument}

In order to achieve the study purpose, the researchers administered a questionnaire consisted of 11 five-level Lickert Scale items and 3 open-ended written questions at the end. The questionnaire adopted Johnson (2013) instrument as a guideline in deciding the themes of the variables. The three themes identified for were general perceptions of flipped learning (Items 1, 2, 3, 9 and 11), roles of video and social media (Items 4, 6, 7, and 8) and time (Items 5 \& 10).

\subsection{Data collection procedure}

The data collection procedure began with briefing students on how flipped learning concept is implemented in the classroom. The first step of flipped learning was preparing materials for the grammar presentation and deciding which learning portal to be used as the flipped learning platform. Secondly, students were to group themselves and shoot a video for grammar presentation. Thirdly, they decide which video service they will use to publish their video. The fourth step was to make the other students accountable for watching the video. This was done by providing exercises or online discussion related to the video. And finally the last step was to reinforce information and knowledge gained from the video by having discussion and group activities in the classroom. After all groups have completed the grammar presentation videos, they were then asked to complete the questionnaire on their perceptions of flipped classroom that they have implemented in learning grammar. 


\subsection{Data Analysis}

The data gathered from the questionnaire were entered and analysed in SPSS version 24. Descriptive statistics of frequency was selected to ascertain the levels of students' perceptions in the Lickert Scale.

\section{Findings and Discussion}

The results of the quantitative data are presented under three themes which include general perceptions of flipped learning, videos and media, and time.

\subsection{Background of respondents}

The number of respondents is 120 with 37.5 percent were male and the 62.5 percent were female. Eighty six point seven percent were 18-21 years of age while 13.3 percent were 22-25 years of age.

Table 1: Respondents Background Information

\begin{tabular}{|l|l|l|c|c|}
\hline No & Item & & $n$ & Percentage (\%) \\
\hline \multirow{2}{*}{1} & \multirow{2}{*}{ Sex } & Male & 45 & 37.5 \\
\cline { 3 - 5 } & & Female & 75 & 62.5 \\
\hline \multirow{2}{*}{ Age } & \multirow{2}{*}{} & $18-21$ years & 104 & 86.7 \\
\cline { 3 - 5 } & & $22-25$ years & 16 & 13.3 \\
\hline
\end{tabular}

\subsection{Flipped Learning}

There were five items that assessed students' general perceptions on flipped learning. The items are item 1, 2, 3, 9 and 11. Below are the descriptions of the results for each item.

Item 1: The flipped classroom is more engaging than the traditional classroom

This item showed a positive response from students. Sixty nine students $(57.5 \%)$ agree while twenty six students $(21.7 \%)$ strongly agree to this statement. (See Table 2 ). The results showed that majority of the students enjoys flipped learning more than traditional classroom.

Table 2

\section{FL more engaging than traditional CR}

\begin{tabular}{llr|r} 
& Frequency & \multicolumn{2}{c|}{ Percent } \\
\hline Valid & 4 & 3.3 \\
\cline { 2 - 4 } & Disagree & 21 & 17.5 \\
Neither Agree Nor & & 57.5 \\
Disagree & 69 & 21.7 \\
\hline Agree & 26 & 100.0 \\
\cline { 2 - 3 } & Strongly Agree & 120 & \\
\cline { 2 - 3 } & &
\end{tabular}

Item 2: I would recommend the flipped classroom to a friend

This item also showed a strong positive response from the students. Ninety six students $(80 \%)$ answered either agree or strongly agree with this statement. (See 
Table 3). This results implied that it is worth it to recommend flipped classroom to their friends.

Table 3:

\section{Recommend FL to a friend}

\begin{tabular}{ll|r|r|} 
& Frequency & \multicolumn{2}{c|}{ Percent } \\
\hline Valid & 6 & 5.0 \\
\cline { 2 - 3 } & Disagree & 18 & 15.0 \\
Neither Agree Nor & & 68 & 56.7 \\
\cline { 2 - 3 } & Disagree & 28 & 23.3 \\
\hline Agree & 120 & 100.0 \\
\hline Strongly Agree & Total &
\end{tabular}

Item 3: The flipped classroom gives me better opportunities to interact with other students

This item showed the strongest response from students from this theme. Ninety seven students $(80.8 \%)$ answered either agree or strongly agree to this statement. (See Table 4). The results showed that students really enjoyed interacting with other students in flipped learning classroom. By interacting with other students meant that they were actively engaged in the activities that helped achieved meaningful learning.

Table 4

FL better opportunities to interact with other students

\begin{tabular}{llr|r} 
& Frequency & & Percent \\
\hline Valid & 5 & 4.2 \\
\cline { 2 - 4 } & Disagree & 17 & 14.2 \\
Neither Agree Nor & & 42.5 \\
\cline { 2 - 3 } & Disagree & 51 & 38.3 \\
\hline Agree & 46 & 100.0 \\
\hline Strongly Agree & 120 & \\
\cline { 2 - 3 } & &
\end{tabular}

Item 9: I feel that the flipped classroom has improved my grammar understanding

One of the two items in this theme if general perceptions of flipped classroom that had received a mixed response from the students. This item stated that I feel that the flipped classroom has improved my grammar understanding. Five students (4.1\%) responded strongly disagree or disagree while thirty five $(29.2 \%)$ neither agree nor disagree to this statement. However, 80 students $(66.6 \%)$ agree or strongly disagree that flipped classroom has improved their grammar understanding. (See Table 5). These results agreed with the findings by Knight and Wood (2005) who found that while results for student learning were positive, both students and teachers found that there was some initial discomfort adjusting to the decreased lectures which meant less transmission of information from instructor to student which led to some of these students feeling flipped learning has not really improved their grammar understanding. 
Table 5

I feel that FC has improved my Grammar understanding

\begin{tabular}{llr|r} 
& \multicolumn{2}{c}{ Frequency } & Percent \\
\hline Valid & 1 & .8 \\
\cline { 2 - 4 } & Strongly Disagree & 4 & 3.3 \\
\cline { 2 - 4 } & Neither Agree Nor & 35 & 29.2 \\
Disagree & & \\
\hline Agree & 64 & 53.3 \\
\hline Strongly Agree & 16 & 13.3 \\
\hline Total & 120 & 100.0 \\
\hline
\end{tabular}

Item 11: I am more motivated to learn grammar through the flipped classroom

The next item that had received mixed response from the students was Item 11. Students were hesitant about flipped classroom improving their motivation. Out of 120 responses, thirty five $(29.2 \%)$ stated neither agree nor disagree while ten $(8.3 \%)$ (See Table 6) stated either strongly disagree or disagree to this statement. This is probably due to the adjustment students have to experience in learning grammar using the new instructional model-flipped learning. By adopting to the new model, it led students to having mixed feelings thus affecting their motivation level. Nevertheless, seventy five $(62.5 \%)$ responded agree or strongly agree to this statement

Table 6

\section{I am more motivated to learn grammar through the flipped classroom}

\begin{tabular}{|c|c|c|c|}
\hline & & Frequency & Percent \\
\hline \multirow{6}{*}{ Valid } & Strongly Disagree & 1 & .8 \\
\hline & Disagree & 9 & 7.5 \\
\hline & $\begin{array}{l}\text { Neither Agree Nor } \\
\text { Disagree }\end{array}$ & 35 & 29.2 \\
\hline & Agree & 54 & 45.0 \\
\hline & Strongly Agree & 21 & 17.5 \\
\hline & Total & 120 & 100.0 \\
\hline
\end{tabular}

\subsection{Videos and social media}

Videos and social media play an important role in a flipped classroom since most lessons are carried out via videos and other media. As a result, it is crucial to obtain students' perceptions regarding the use of videos and other social media. Item 4, 6, 7 and 8 addressed this theme in the questionnaire. Below are the descriptions of the results for each item.

Item 4: I like watching the lessons on videos

This item shows a strong positive response from the students with ninety $(75 \%)$ out of 120 responded agree or strongly agree (See Table 7) that they like watching the lessons on videos. Only one $(0.8 \%)$ strongly disagree and six $(5 \%)$ disagree to the statement while another twenty two (18.3\%) stated neither agree nor disagree. 
Table 7

I like watching the lessons on videos

\begin{tabular}{llr|r} 
& Frequency & Percent \\
\hline Valid & 1 & .8 \\
\cline { 2 - 4 } & Strongly Disagree & 6 & 5.0 \\
\cline { 2 - 3 } & Nisagree & 22 & 18.3 \\
Disther Agree Nor & & \\
\hline Agree & 52 & 43.3 \\
\hline Strongly Agree & 38 & 31.7 \\
\hline Total & 120 & 100.0 \\
\hline
\end{tabular}

Item 6: Social media is an important part in my learning

This item showed the strongest positive response from the students with ninety two $(76.7 \%)$ stated agree or strongly agree that social media plays an important part in their learning.

Table 8

Social media is an important part in my learning

\begin{tabular}{llr|r|} 
& \multicolumn{2}{c}{ Frequency } & Percent \\
\hline Valid & Strongly Disagree & 7 & 1.7 \\
\cline { 2 - 4 } & Disagree & 19 & 5.8 \\
\cline { 2 - 4 } Neither Agree Nor & & 15.8 \\
Disagree & 53 & 44.2 \\
\hline Agree & 39 & 32.5 \\
\hline Strongly Agree & 120 & 100.0 \\
\hline Total & & \\
\hline
\end{tabular}

Item 7: I regularly watch the video assignment

While majority of the students liked to watch the lessons on video, there were a mixed response when it came to watching the video assignment regularly. Forty two $(35 \%)$ stated neither agree nor disagree while $16(13.3 \%)$ stated strongly disagree or disagree to the statement (See Table 9). Despite the ambivalent responses, sixty two $(51.6 \%)$ still stated that they regularly watched the video assignment.

Table 9

I regularly watch the video assignment

\begin{tabular}{|c|c|c|c|}
\hline & & Frequency & Percent \\
\hline \multirow{6}{*}{ Valid } & Strongly Disagree & 1 & 8 \\
\hline & Disagree & 15 & 12.5 \\
\hline & $\begin{array}{l}\text { Neither Agree Nor } \\
\text { Disagree }\end{array}$ & 42 & 35.0 \\
\hline & Agree & 46 & 38.3 \\
\hline & Strongly Agree & 16 & 13.3 \\
\hline & Total & 120 & 100.0 \\
\hline
\end{tabular}


Item 8: I would rather have traditional teacher led lesson than watching a lesson video

This item received the most undecided response among all items under the theme video and social media. Fifty two (43.3\%) stated they neither agree nor disagree with this statement (See Table 10). This was probably due to the transition period of adjusting from a traditional classroom to an interactive one.

Table 10

I would rather have traditional teacher led lesson than watching a lesson video

\begin{tabular}{llr|r|} 
& Frequency & \multicolumn{1}{c}{ Percent } \\
\hline Valid & 3 & 2.5 \\
\cline { 2 - 4 } & Strongly Disagree & 16 & 13.3 \\
\cline { 2 - 4 } & Disagree & 52 & 43.3 \\
Deither Agree Nor & & \\
\hline Disagree & 35 & 29.2 \\
\hline Agree & 14 & 11.7 \\
\hline Strongly Agree & 120 & 100.0 \\
\hline Total &
\end{tabular}

\subsection{Time}

For the theme of time, two items were addressed. The items were Item 5 and 10. These items investigated how much time students were spending at home doing grammar related homework and how they were spending their additional classroom time. Below are the descriptions of the results for each item.

Item 5: I am spending less time working on traditional grammar homework

This item showed a slim difference of responses between the five Lickert Scales. 65 $(54.2 \%)$ stated agree or strongly agree while $55(45.8 \%)$ stated strongly disagree, disagree or neither agree not disagree for this statement (See Table 11).

Table 11

I am spending less time working on traditional grammar homework

\begin{tabular}{rlr|r} 
& Frequency & \multicolumn{1}{c}{ Percent } \\
\hline Valid & 3 & 2.5 \\
\cline { 2 - 4 } & Strongly Disagree & 13 & 10.8 \\
\cline { 2 - 4 } & Nisagree & 39 & 32.5 \\
Deither Agree Nor & & 44.2 \\
\hline Disagree & 53 & 10.0 \\
\hline Agree & 12 & 100.0 \\
\hline Strongly Agree & 120 & \\
\hline Total & &
\end{tabular}

Item 10: Flipped classroom gives me less class time to learn grammar

This is the last item under the theme time and the results showed a mixed response between neither agree nor disagree and agree. Forty six (38.3\%) stated neither agree nor disagree while forty three $(35.8 \%)$ stated agree that flipped classroom gave them less class time to learn grammar (See Table 12). 
Table 12

FC gives me less class time to learn grammar

\begin{tabular}{llr|r|} 
& Frequency & \multicolumn{2}{r|}{ Percent } \\
\hline Valid & 3 & 2.5 \\
\cline { 2 - 4 } & Strongly Disagree & 19 & 15.8 \\
\cline { 2 - 4 } & Nisagree & 46 & 38.3 \\
Disther Agree Nor & & \\
\hline Agree & 43 & 35.8 \\
\hline Strongly Agree & 9 & 7.5 \\
\hline Total & 120 & 100.0 \\
\hline
\end{tabular}

\subsection{Open ended questions}

There were three open ended questions at the end of the questionnaire. The questions were as follows:

1. What are the advantages of the flipped classroom in learning grammar?

2. What are the disadvantages of the flipped classroom in learning grammar?

3. What improvements would you recommend to improve learning grammar in the flipped classroom?

\subsubsection{Advantages of the flipped classroom}

Out of the 120 respondents surveyed, it should be noted that each student listed at least one advantage of the Flipped Classroom. The responses have been tabulated in the table below.

\begin{tabular}{|l|c|}
\hline Item & $\begin{array}{l}\text { No of } \\
\text { responses }\end{array}$ \\
\hline Can learn better and improve Grammar & 28 \\
\hline Better understanding of topic before class & 27 \\
\hline Fun to watch videos, more engaging and not boring & 26 \\
\hline More interaction with others & 24 \\
\hline Increase confidence in speaking & 18 \\
\hline Less time consuming and allowing more time for discussion & 17 \\
\hline Self -pacing/ Can watch video repeatedly at anytime and anywhere & 10 \\
\hline No comment & 9 \\
\hline Encourage team work & 8 \\
\hline Can be more creative in presentation & 6 \\
\hline
\end{tabular}

\subsubsection{Disadvantages of the flipped classroom}

Out of the 120 respondents surveyed, it should be noted that each student listed at least one disadvantage of the Flipped Classroom. The responses have been tabulated in the table below. 


\begin{tabular}{|l|l|}
\hline Item & $\begin{array}{l}\text { No of } \\
\text { responses }\end{array}$ \\
\hline Errors in explanations in video & 32 \\
\hline Unclear explanation/difficult to understand & 31 \\
\hline Poor internet connection & 24 \\
\hline Time consuming to prepare & 17 \\
\hline Not all students are keen to participate & 12 \\
\hline Not all will view videos & 10 \\
\hline Cannot ask questions on the spot & 9 \\
\hline Poor quality of video & 9 \\
\hline Easily lose focus while watching video & 8 \\
\hline No comment & 7 \\
\hline Traditional classroom is better & 4 \\
\hline Lack of communication between instructor and students & 3 \\
\hline Classroom condition not conducive & 2 \\
\hline Not suitable for learning & 1 \\
\hline
\end{tabular}

\subsubsection{Recommendations to improve flipped classroom}

Out of the 120 respondents surveyed, it should be noted that each student listed at least one Recommendation to improve the Flipped Classroom. The responses have been tabulated in the table below.

\begin{tabular}{|l|l|}
\hline Item & $\begin{array}{l}\text { No of } \\
\text { responses }\end{array}$ \\
\hline $\begin{array}{l}\text { Provide more exercises/discussion/activities for online } \\
\text { learning }\end{array}$ & 23 \\
\hline No comment & 21 \\
\hline Nothing! Absolutely love it. & 17 \\
\hline Give more time to prepare & 17 \\
\hline Have better quality and shorter video (less than 10 minutes) & 15 \\
\hline Encourage active participation & 7 \\
\hline Do not limit presentation time & 6 \\
\hline Incorporate games as part of activities & 6 \\
\hline Recommend suitable video editor & 5 \\
\hline Facilities in the classroom should be improved & 4 \\
\hline Limit destructive sounds while shooting video & 2 \\
\hline Record video in the classroom only & 2 \\
\hline $\begin{array}{l}\text { Drama/musical as part of activities and apply grammar } \\
\text { knowledge in it }\end{array}$ & 1 \\
\hline
\end{tabular}




\section{Implication}

This study sheds light on the delivery of instruction in education of the $21^{\text {st }}$ century. Technology enables ubiquitous access to information from mobile phones, tablets, computers. We no longer need teachers to be the sole provider of materials and information. With technology, student centred learning is enhanced and teachers act as the facilitator or a guide to move students towards asynchronous student centred learning environment. Being student centred means they (the students) take charge of their own learning at their own pace. Hence, flipped classroom offers a new reinvention to those educators who are looking forward from being a "sage on the stage" to the guide on the side (Johnson, 2013).

But one should remember that it takes time for a new pedagogical instruction to blend in the current classroom practice. There will be some initial discomfort adjusting to less transmission of information from instructor to student. This is indeed very crucial for flipped classroom adopters to understand. A transition to a new model, regardless of success, may involve uneasiness among the participants (Knight and Wood, 2005).

This study is just one example of how instructors can change their way of teaching in a flipped classroom environment. Flipped learning in this study focused on students self-pace learning in a student centred environment. Students were being briefed at the beginning of the course the tasks they needed to complete. The instructor gave students ample time to prepare themselves and made sure they met the deadline of the assignments. Most importantly, they were given significant opportunity to reflect on their own learning.

In addition, this study also showed an example of how to implement a flipped classroom. One need to remember that flipped classroom is not about video or technology. It is mainly about effective use of classroom time. It allows more collaboration and discussion to construct learning together. Therefore, educators can still continue to experiment with flipped classroom strategies to suit their curricular needs.

\section{Conclusion}

As a conclusion, the main purpose of this study was to explore and investigate students' perceptions of the flipped classroom. Flipped classroom is a shift from a traditional teacher led instructions to an active approach of student centred learning. The heart of a flipped classroom in this study was to move a passive teacher centred learning environment to an active student entered learning environment. To ensure the effectiveness of a flipped classroom, record a video of presentation/lecture for 10-20 minutes. The video should be available on demand and viewed prior to face to face lecture. It should also integrate with learning activities in social media (e.g padlet, smart2ums) and the learning activities in classroom.

This study also tried to answer several questions pertaining to flipped learning. A total of 120 students were asked to participate in this study and strong positive responses were gathered from them as most of them favoured flipped classroom in 
learning grammar. It is therefore recommended that based on the results of this study, the teaching of grammar can be more fun and interactive by adopting the flipped classroom.

The flipped classroom can indeed create rich and meaningful learning activities. Students no longer need lessons that comprised of instructors and materials. It is evident in this study that they enjoy learning at their own pace and the learning various activities integrated into the lessons. Perhaps there is one question of how do instructors make up for the plenty of extra time in class? Future research can be done on this but the best one to be will be based on learners needs.

\section{References}

Alias, Abdul Karim. (2010). Flipped classroom: Total classroom makeover. Retrieved from: https://www.openlearning.com/courses/flippedlearning

Alias, Abdul Karim. (2014). Flipped classroom, mobile learning, whatsapp, and learning nuggets. Retrieved from: http://onestoplearning.blogspot.my/search?q=flipped+classroom

Baeten, M., Kyndt, E., Struyven, K. \& Dochy, F. (2010). Using student-centred learning environments to stimulate deep approaches to learning: Factors encouraging or discouraging their effectiveness. Educational Research Review, 5(3).

Baker, J. W. (2000). The 'classroom flip: Using web course management tools to become the guide by the side. 11th International Conference on College Teaching and Learning, Jacksonville, Florida, United States, April 12-15.

Bishop, J.L. \& Verleger, M.A. (2013). The flipped classroom: A survey of the research. 120th American Society of Engineering Education Annual Conference \& Exposition, Atlanta, Georgia, United States, June 23-26.

Butt, A. (2014). Student views on the use of a flipped classroom approach: Evidence from Australia. Business Education and Accreditation,6 (1).

Johnson, G. B. (2013). Students perceptions of the flipped classroom. (Doctoral dissertation, The University of British Columbia). Retrieved from https://open.library.ubc.ca/cIRcle/collections/ubctheses/24/items/1.0073641

Knight, J. K., \& Wood, W. B. (2005). Teaching More by Lecturing Less. Cell Biology Education, 4(4), 298-310.

Lage, M.J., Platt, G.J. \& Treglia, M. (2000) "Inverting the classroom: A gateway to creating an inclusive learning environment," Journal of Economic Education, vol. 31(1), p. 30-43

Prince, M. (2004). Does active learning work? A review of the research. Journal of Engineering Education, 93(3)

Strayer, J. F. (2008). The effects of the classroom flip on the learning environment: A comparison of learning activity in a traditional classroom and a flip classroom that used an intelligent tutoring system (Doctoral dissertation, The 
Ohio State University). Retrieved from http://etd.ohiolink.edu/sendpdf.cgi/Strayer\%20 